\title{
Economic and Breeding Value of Apple Varieties in Azerbaijan Republic
}

\author{
Aladdin Sadikov \\ Research Institute of Fruit Growing and Tea Production, Ministry of Agriculture of the Republic of Azerbaijan, Zardabi, Cuban District, \\ Azerbaijan \\ Email address: \\ sadikov-56@mail.ru

\section{To cite this article:} \\ Aladdin Sadikov. Economic and Breeding Value of Apple Varieties in Azerbaijan Republic. Sadikov Aladdin the Son Nemat. American \\ Journal of Agriculture and Forestry. Vol. 8, No. 2, 2020, pp. 53-57. doi: 10.11648/j.ajaf.20200802.12
}

Received: November 8, 2019; Accepted: March 19, 2020; Published: May 18, 2020

\begin{abstract}
Agriculture is one of the leading industries in Azerbaijan, and fruit science is developing on a scientific basis. In the orchards the apple plant takes the first place, and in these gardens there are applied varieties of national selection, introduction varieties, selection varieties of the Scientific-Research Institute of Fruit and Tea. The history of selection in the Azerbaijan Republic began in 1932 by researchers of the Guba Experiment Station. The father parent is used mainly for breeding, such as those obtained by national selection, and as the mother parent used introductioned varieties $\left(\mathrm{F}_{1}\right)$ for breeding purposes: Anatolu, Arzu, Badami, Bichin goren, Vystavochnaya, New Rosmarine, Guba saffron, Kamshirin, Naila, Sona apple, Samed Vurgun, Neftchilara hadiyya, Azerbaijan reneti and so on. Varieties have been obtained these varieties are widely distributed in the regions of Azerbaijan, which have different soil and climatic conditions. To eliminate the deficiencies in these varieties, 23 new breeds have been acquired by repeated hybridization $\left(\mathrm{F}_{2}\right)$ since 1985. These varieties (Nigar, Marfa, Sulkh, Sevinj, Chyrqqala, Emil, Shabran, Nyubar, Khazar, Vatan, Elvin, Davamly, Autumn Guba, winter Guba, Ulvi, Mahmari, Zumrud, Eldar, Nuran, Gizil Taj, Gobustan, Sarvan, Sadaf) submitted to the State Commission for Selection Achievement Testing and Protection. Varieties of Autumn Guba, Winter Guba, Elvin and Sevinj are zoned. The article provides information on the yield, productivity, some quality indicators, the sustainability of the vegetation period and economic efficiency as a result of research.
\end{abstract}

Keywords: Apple Sorts, Crop Giving, Productivity, Quality, Indicators, Vegetation, Profitability, Azerbaijan

\section{Introduction}

There are numerous varieties and forms of apples in Azerbaijan that have been of folk selection, established scientifically in the field and purposeful breeding and at the same time introduced. Nowadays the presence of extremely promising varieties in fruit orchards and the end of the pomological age of most varieties as a result requires the creation of new high-yielding varieties of high-quality and high-grade varieties with high genetic quality. During the years of research (1985-2017), the selection of modern varieties of folk breeding and artificial breeding, as well as the introduction varieties, have been investigated for their effective use in improving the composition of new varieties. Intensive gardening requires the creation of new varieties with high productivity and long-term soil-climatic conditions with long service life. In this regard, we have achieved the selection varieties that of ripening different periods, short, high-yielding, meeting the requirements of mechanization, fast productive, disease-resistant, quality, productive and profitable.

\section{Creating New Varieties with Traditional Breeding Methods}

Fruit growing in the Republic of Azerbaijan is one of the most important branches of agriculture. The total area of fruit stands for 2019 was 182.3 thousand ha, of which $30 \%$ are apple.

Since 1982, about 200 local, introduced varieties and varieties obtained by breeding the Research Institute for Fruit and Tea have been introduced into the gene pool. Over the past 25-40 years, their agrobiological properties have been 
studied in the propagation zones of introduced varieties [1].

Much work on the cultivation of new high-quality apple varieties at the Research Institute for Fruit Growing and Tea Growing was begun in 1932 by researchers at the Cuban Experimental Station. Apple varieties created here (Anatoli, Arzu, Badama, Bichin Gehren, Vystavochny, Yeni Rosmarin, Cuban saffron, Kemshirin, Naila, Sona alma, Samed Vurgun, Neftchilere hediyye, Renet Azerbaijan, etc.) were widely tested in various soil and climatic regions of Azerbaijan. [2, $3]$.

Given the shortcomings of zoned and new apple varieties, in 1985, selection work was begun in Azerbaijan by repeated $\left(\mathrm{F}_{2}\right)$ hybridization and crossbreeding of new varieties with the best standard varieties. As a result of a stationary test of promising hybrids, the State Commission for the Conservation and Testing of Selection Achievements selected 23 best apple varieties: Nigar, Marfa, Sulkh, Sevinj, Chyraqqala, Emil, Shabran, Nyubar, Khazar, Vatan, Elvin, Davamly, Autumn Guba, winter Guban, Ulvi, Mahmari, Zyumrud, Eldar, Nuran, Gizil Taj, Gobustan, Sarvan, Sadaf. Varieties of Autumn Guba, Winter Guba, Elvin and Sevinj are zoned $[4,5,6]$.

The article presents the results of studies on the early maturity, yield, quality of fruits, the duration of vegetation and the profitability of new breeding varieties of apple trees.

For the successful development of highly productive gardening, the production of aesthetically high-quality fruits, the choice of variety is of paramount importance [7].

Currently, in connection with the intensification of horticulture, transferring it to an industrial basis, a number of additional requirements are made to the variety. For specialized gardens with compacted stands, varieties of the intensive type are desirable. Trees of such varieties must meet the following requirements: have moderate growth, small, compact, naturally well sparse roots, early to bear fruiting, bear fruit regularly, form fruits of high consumer and aesthetic qualities with a high content of valuable nutrients and vitamins; achieve optimal removable maturity at the time of collection [8].

Azerbaijan is the oldest center of fruit culture and the center for the formation of a number of valuable fruit plants.

In the implementation of the tasks at the experimental base of the Scientific Research Institute Fruit and Tea growing in 1985-2018, research work was carried out on the selection of apple trees. As a result of selection work by repeated crossing 104506 pcs were isolated and the operation of crossing from the $\left(\mathrm{F}_{2}\right) 11999$ pcs. in 105 combinations, 6153 pcs. fruits and 3330 pcs. Hybrids were planted for 2-3 years in the nursery. From this nursery 199 pcs. seedlings on high cultural grounds were elected elite a selection hybrid garden was laid and in the years 1989-2016,. As a result 23 best apple varieties were selected [9] of stationary testing of promising hybrids.

The purpose of research, conditions, material and methodology. The main goal of the work is to create new apple varieties adapted to the environmental conditions of the Cuba-Khachmaz zone, combining the best quality indicators of introduced and local varieties.
The experimental plot is located on the territory of the auxiliary experimental farm of the Research Institute for Fruit Growing and Tea Production at the Ministry Agricultural of Azerbaijan Republic in the Guba region, at an altitude of $750 \mathrm{~m}$ above sea level.

The climate of the Guba region is moderately warm. At the same time, the Guba region is significantly affected by cold air masses invading Azerbaijan from the north-west and north The climate of the foothill part is semi-humid, moderately cold. According to long-term data, the average annual air temperature is $9.8^{\circ} \mathrm{C}$, and in the years of our research it was $10.0^{\circ} \mathrm{C}$. According to long-term data, the absolute maximum temperature (July-August) reaches $+37.0^{\circ} \mathrm{C}$, during the years of experience $+36.1 \ldots+37.3^{\circ} \mathrm{C}$. According to long-term data, the average absolute minimum temperature varies from -13.0 to $-16.0^{\circ} \mathrm{C}$ in January-February, from 15.0 to $18.0^{\circ} \mathrm{C}$ over the years of research.

According to long-term data, the average annual precipitation is $527 \mathrm{~mm}$, in the years of experience - 576.9 $\mathrm{mm}$.

The soil cover of the mid-mountain part of the zone is represented by mountain (fulvous and brown) soils and chestnut garden soils.

In the creation of new breeding varieties, the local, introduced and breeding varieties Scientific Research Institute Fruit and Tea Groving were used as initial forms, which were distinguished by good productivity and high palatability.

Hybridization, study and selection of hybrid seedlings in a breeding nursery and garden were carried out according to the program and methodology for selection of fruit, berry and nut-bearing crops All- Union SRIPB after I. V. Michurina [10]. Evaluation of the primary variety study was carried out according to the program and methodology of selection of fruit, berry and nut-bearing crops of All- UnionSRIPB [11].

\section{Research Results}

The aim of the research was to develop new varieties of apple trees combining the best production and biological indicators: early maturity, yield, fruit quality, growing season, long shelf life, profitability, etc.

Immaturity is an integral quality of apple varieties of intensive type. As already noted, the task was set to create new varieties of apple trees that enter fruiting on vigorous rootstock no later than 5-6th year after planting. Apple tree seedlings, as a rule, enter the fruiting season on the 9-16th year after sowing. There is an opinion that late entry into fruiting in an apple tree is determined by a long juvenile period. At the same time, cases of much earlier onset of fruiting of seedlings of this culture were noted [12].

As a result of studying this issue, it was established that the varieties of Chiraggala, Nyubar, Khazar, Elvin and Sarvan grafted on vigorous rootstocks enter fruiting for 4-5 years after planting, the varieties Nigar, Marfa, Sulkh, Sevindzh, Emil, Shabran, Vatan, Davamly, Winter Guba, Autumn Guba, Ulvi, Nuran and Sadaf - for 5-6 years, the 
variety Zyumrud - for 7-8 years, the varieties Gobustan, Eldar, Makhmari and Gizil Taj - for 8-9 years.

Over the years of research (2015-2018), depending on the variety and climatic conditions, it was found that the yield of the summer variety Nigar was higher $(180 \mathrm{c} / \mathrm{ha})$ than the yield of Papirovka variety ( $60 \mathrm{c} / \mathrm{ha}$ ). The productivity of the autumn variety Marfa amounted to $160 \mathrm{c} / \mathrm{ha}$, while the productivity of the control variety Azerbaijan was $130 \mathrm{c} /$ ha. The difference between high yields and the standard for autumn varieties was $30 \mathrm{c} /$ ha. The yield of winter varieties ranged from 190 centner / ha (Sulkh) and 230 centner / ha (Sevinj and Gizil Taj).

The highest yields of Sevinj, Gizil Taj are $230 \mathrm{c} / \mathrm{ha}$, Sadaf - 227 c / ha, Vatan - 225 c / ha. In these varieties, the yield was higher by 15-20 prices / ha, compared with the control variety Elvin. The yield of the remaining varieties is intermediate.

One of the main indicators characterizing quality and, above all, marketability is the mass of the fruit. The fruit weight ranged from 110 to $165 \mathrm{~g}$ in the studied new breeding varieties of apple trees. Compared to the control varieties of large-fruity, Makhmari (165 g), Gizil Taj (159 g), Zyumrud (155 g), Sarvan (110 g), Chiraggala (120 d) and the winter Guba $(120 \mathrm{~g})$. The fruit volume is $138-189 \mathrm{~cm}^{3}$, the taste rating is from 4.0 to 5.0 points. All varieties give fruit yield for commercial varieties at the level of $77-88 \%$. The varieties: Sadaf, Sarvan, Gizil Taj, Makhmari, Ulvi and Sulkh have high marketability and consumer value.

The soluble solids in the fruits is from $10.4 \%$ (Nigar) to $12.9 \%$ (Gobustan), the amount of sugars ranges from $6.43 \%$ (Chiraggala) to $10.9 \%$ (Sadaf), ascorbic acid from $0.77 \mathrm{mg} / \%$ (Emil) to $6.21 \mathrm{mg} / \%$ (Gobustan) per $100 \mathrm{~g}$ of crude material.

Among the main breeding tasks for the cultivation of new breeding apple varieties was the creation of varieties resistant to diseases, mainly scab, the prevalence of which in fruit growing zones sometimes reaches considerable sizes. It should be noted that many standard and promising varieties of apple trees do not have immune to scab and are very affected by this disease in wet years.

In Azerbaijan in the Guba-Khachmaz zone over the years of research (2015-2018), depending on the variety and climatic conditions, new breeding apple varieties were affected by scab 0.5-1.2 points. Varieties Eldar, Emil, Chiraggala, Ulvi, Makhmari and Sarvan are especially resistant (0.5-0.7 points) to scab. Susceptibility to scab is shown by varieties Marfa, Sulkh, Winter Guba, Autumn Guba and Sevinj (1.0-1.2 points). The remaining apple varieties are not very susceptible to scab, the susceptibility ranged from 0.7 to 0.9 points.

During 2015-2018, we studied the keeping quality of fruits of various apple varieties. The fruits were stored in a dark, cool room at a temperature of $9.5-11.4^{\circ} \mathrm{C}$ during the laying period and $4.6-7.4^{\circ} \mathrm{C}$ in the winter. Humidity ranged from $61.7-79.4 \%$. As the research results showed, the shelf life of the fruits in the studied varieties was 20-25 days for the summer variety Nigar, 40-45 days for the Marfa autumn variety, and from 110 (Chiraggala) to 160 (Eldar) days for winter varieties, with a natural decrease from 9.92 to $13.4 \%$.

As follows from our observations, in the Guba-Khachmaz zone of the Azerbaijan Republic, the period from the beginning of the blooming of fruit buds to the end of leaf fall, depending on the variety and meteorological conditions of the year, covers $215-235$ days. The shortest vegetation period (215-217 days) has the varieties Gobustan, Gizil Taj, Nuran, Eldar, Zyumrud, Mahmari, Vatan, Khazar, Nyubar and Ulvi, the longest (231-235 days) Sadaf, winter Guba, Sulkh, Nigar, Shabran, Martha and Sevinj. The sum of effective air temperatures above $+5^{\circ} \mathrm{C}$ at the time of leaf falling, depending on the variety, is $3452.8-3516.6^{\circ} \mathrm{C}$.

Table 1. The main economic and biological indicators of breeding apple varieties.

\begin{tabular}{|c|c|c|c|c|c|c|c|}
\hline Sort & Term Ripening & Fruiting & Productivity c/ha & $\begin{array}{l}\text { Average weight } \\
\text { Fruit g }\end{array}$ & $\begin{array}{l}\text { Fetal volume } \\
\text { см }^{3}\end{array}$ & $\begin{array}{l}\text { Taste assessment } \\
\text { in points }\end{array}$ & $\begin{array}{l}\text { Marketa } \\
\text { bility, \% }\end{array}$ \\
\hline Papirovka (c) & summer & $5-6$ & 120 & 110 & 138 & 4,0 & 77 \\
\hline Nigar & summer & $5-6$ & 180 & 110 & 138 & 4,2 & 85 \\
\hline Azerbaijan (c) & autumn & $5-6$ & 130 & 130 & 158 & 4,1 & 79 \\
\hline Marfa & autumn & $5-6$ & 160 & 140 & 169 & 5,0 & 86 \\
\hline Elvin (c) & winter & $4-5$ & 210 & 128 & 151 & 5,0 & 87 \\
\hline Sulh & winter & $5-6$ & 190 & 140 & 169 & 5,0 & 87 \\
\hline Chiraqqala & winter & $4-5$ & 215 & 120 & 148 & 4,1 & 83 \\
\hline Emil & winter & $5-6$ & 220 & 140 & 169 & 5,0 & 84 \\
\hline Shabran & winter & $5-6$ & 215 & 140 & 169 & 4,2 & 85 \\
\hline Nubar & winter & $5-6$ & 205 & 145 & 173 & 5,0 & 82 \\
\hline Khazar & winter & $4-5$ & 211 & 130 & 158 & 4,4 & 86 \\
\hline Vatan & winter & $4-5$ & 225 & 130 & 158 & 5,0 & 85 \\
\hline Davamli & winter & $5-6$ & 214 & 130 & 158 & 5,0 & 86 \\
\hline Kubinskoe osenneye & winter & $5-6$ & 207 & 130 & 158 & 4,0 & 88 \\
\hline Ulvi & winter & $5-6$ & 230 & 140 & 169 & 4,9 & 87 \\
\hline Makhmari & winter & $8-9$ & 221 & 165 & 193 & 4,0 & 88 \\
\hline Zumrud & winter & $7-8$ & 211 & 155 & 184 & 4,5 & 87 \\
\hline Eldar & winter & $8-9$ & 200 & 141 & 170 & 4,8 & 79 \\
\hline Nuran & winter & $5-6$ & 207 & 145 & 173 & 4,2 & 79 \\
\hline Qizil tag & winter & $8-9$ & 230 & 159 & 189 & 5,0 & 87 \\
\hline
\end{tabular}




\begin{tabular}{|c|c|c|c|c|c|c|c|}
\hline Sort & Term Ripening & Fruiting & Productivity c/ha & $\begin{array}{l}\text { Average weight } \\
\text { Fruit g }\end{array}$ & $\begin{array}{l}\text { Fetal volume } \\
\text { см }^{3}\end{array}$ & $\begin{array}{l}\text { Taste assessment } \\
\text { in points }\end{array}$ & $\begin{array}{l}\text { Marketa } \\
\text { bility, \% }\end{array}$ \\
\hline Qobustan & winter & $8-9$ & 220 & 150 & 179 & 4,8 & 83 \\
\hline Sarvan & winter & $4-5$ & 222 & 154 & 183 & 4,7 & 87 \\
\hline Sadaf & winter & $5-6$ & 227 & 140 & 169 & 4,8 & 88 \\
\hline
\end{tabular}

Table 1. Continued.

\begin{tabular}{|c|c|c|c|c|c|c|c|}
\hline Sort & $\begin{array}{l}\text { Soluble solids } \\
\text { content, } \%\end{array}$ & $\begin{array}{l}\text { Sum of } \\
\text { Sugars \% }\end{array}$ & $\begin{array}{l}\text { Ascorbic } \\
\text { acid, mg \% }\end{array}$ & $\begin{array}{l}\text { Affliction scab } \\
\text { in points }\end{array}$ & $\begin{array}{l}\text { Keeping } \\
\text { time, days }\end{array}$ & $\begin{array}{l}\text { Duration } \\
\text { vegetation } \\
\text { days }\end{array}$ & $\begin{array}{l}\text { Comparative } \\
\text { Economics grade } \\
\text { evaluation \% }\end{array}$ \\
\hline Papirovka (c) & 10,3 & 6,55 & 1,57 & 1,0 & $15-20$ & 220 & 100 \\
\hline Nigar & 10,4 & 6,39 & 3,70 & 0,9 & $20-25$ & 235 & 155 \\
\hline Azerbaijan (c) & 10,2 & 6,11 & 1,54 & 0,9 & $25-35$ & 227 & 100 \\
\hline Marfa & 11,2 & 6,60 & 1,94 & 1,0 & $40-45$ & 235 & 125 \\
\hline Elvin (c) & 10,8 & 8,32 & 2,11 & 0,7 & 120 & 234 & 100 \\
\hline Seving & 11,7 & 6,58 & 3,23 & 1,2 & 120 & 234 & 109 \\
\hline Chiraqqala & 11,6 & 6,43 & 1,76 & 0,7 & 110 & 232 & 102 \\
\hline Emil & 11,4 & 6,16 & 0,77 & 0,6 & 116 & 232 & 104 \\
\hline Shabran & 11,8 & 9,14 & 2,11 & 0,8 & 120 & 235 & 102 \\
\hline Nubar & 11,9 & 6,70 & 1,76 & 0,9 & 120 & 216 & -97 \\
\hline Khazar & 11,4 & 7,49 & 2,11 & 0,6 & 129 & 216 & 101 \\
\hline Vatan & 11,9 & 9,60 & 2,11 & 0,9 & 135 & 216 & 106 \\
\hline Kubinskoe zimneye & 10,9 & 9,30 & 1,94 & 1,0 & 133 & 235 & -99 \\
\hline Ulvi & 12,6 & 9,30 & 3,81 & 0,7 & 134 & 217 & 109 \\
\hline Makhmari & 12,6 & 10,81 & 6,51 & 0,7 & 161 & 216 & 105 \\
\hline Zumrud & 11,6 & 9,93 & 5,51 & 0,8 & 135 & 216 & 101 \\
\hline Eldar & 10,9 & 8,62 & 3,56 & 0,5 & 160 & 216 & -95 \\
\hline Nuran & 12,1 & 9,87 & 3,41 & 0,6 & 150 & 215 & -76 \\
\hline Qizil tag & 12,0 & 9,61 & 5,64 & 0,8 & 131 & 215 & 109 \\
\hline Qobustan & 12,9 & 10,77 & 6,21 & 0,6 & 145 & 215 & 104 \\
\hline Sarvan & 11,6 & 10,10 & 5,51 & 0,7 & 160 & 216 & 105 \\
\hline Sadaf & 12,6 & 10,9 & 5,41 & 0,6 & 165 & 231 & 108 \\
\hline
\end{tabular}

The value of a variety of fruit crops for industrial gardening consists of a comprehensive assessment of the main economic indicators. The study of new breeding apple varieties in the Cuba-Khachmaz zone of the Republic of Azerbaijan revealed a number of varieties that excel in some way or other zoned (control) varieties. According to the data given in the table, the yield of the studied apple varieties was different. The highest fruit yield on average over four years was given by varieties Nigar - $180 \mathrm{~kg} / \mathrm{ha}$, Marfa - $160 \mathrm{~kg} /$ ha, Sevindj - $230 \mathrm{~kg} / \mathrm{ha}$, Emil - $220 \mathrm{~kg} / \mathrm{ha}$, Vatan $-225 \mathrm{~kg} /$ ha, Ulvi $230 \mathrm{~kg} / \mathrm{ha}$ ha, Gizil Taj - $230 \mathrm{~kg} / \mathrm{ha}$ and Sadaf $227 \mathrm{~kg} / \mathrm{ha}$, against 120, 130 and $210 \mathrm{~kg} /$ ha for Papirovka, Azerbaijan and Elvin standards. The main indicator of the economic efficiency of varieties is the net income from 1 ha of plantations and the profitability of their production. Economic analysis shows that the profitability of apple varieties and the level of profitability are different. Net profit per 1 ha is: for the summer Nigar variety 7620 AZN (the comparative profitability of this variety is within $150 \%$ ), the standard variety Papirovka is $4680 \mathrm{AZN}$, the autumn variety Marfa is 6648 AZN (the profitability of the varieties was $125 \%$ ), the standard variety Azerbaijan - $5170 \mathrm{AZN}$, winter variety Emil - 9580 AZN, Vatan - 9825 AZN, Ulvi - 10070 AZN, Gizil Taj - 10070 AZN and Sadaf - 9923 AZN (comparative profitability for varieties within 104-108\%), standard grade Elvin - 9090 AZN. Varieties Sulkh, Nyubar,
Autumn Guba, Winter Guba, Eldar and Nuran did not show themselves positively and are inferior to control varieties in all economic indicators.

\section{Findings and Recommendations}

The comparative economic assessment of the varieties allows us to select the most promising, economically profitable varieties from the studied new breeding varieties, selected according to separate biological and economic parameters, due to which the industrial assortment of apple trees in the CubaKhachmaz zone of the Republic of Azerbaijan can be significantly improved: Nigar, Marfa, Sevinj, Emil, Vatan, Makhmari, Gobustan, Gizil Taj, Sarvan and Sadaf.

\section{References}

[1] Sadigov A. N. New selection apple varieties for intensive horticulture in the Republic of Azerbaijan // INTTERNATIONAL CONFERENCE "Diversity, charakterization and utilization of plant genetic resources for enhanced resilience to climate challenge" Octouber 3-4, 2011 Baku, Azerbaijan. - pp. 107-109.

[2] Sadigov A. N. Comparative assessment of apple varieties in Azerbaijan. Siberian Bulletin of Agricultural Science. No. 2 (237), March-April, Novosibirsk, 2014. - from 75-80. 
[3] Sadigov A. N. Valuable apple varieties in Azerbaijan. Agrarian Science No. 4, Moscow, 2014. - p. 22-23.

[4] Sadigov A. N. Quality and marketability indicators of the fruits of new breeding apple varieties in the conditions of the Guba-Khachmaz zone of the Republic of Azerbaijan. Agrarian Bulletin of the Urals, 2015, 10 (140), October. - from. 57-59.

[5] Sadigov A. N. Phenology of apple varieties from the Azerbaijan Scientific Research Institute of Horticulture and Subtropical Crops in the agro-climatic conditions of the GubaKhachmaz zone of the Republic of Azerbaijan. Bulletin of the Saratov State AgroUniversity N. I. Vavilova, No. 7, Saratov, 2014. -- p. 38-40.

[6] Sadigov A. N. Assessment of the suitability of new breeding varieties of apple trees for cultivation in universal gardens. Bulletin of the agro-industrial complex of Stavropol. Scientific and practical journal, No. 2 (14), 2014. - p. 182-184.
[7] Sedov E. N., Zhdanov V. V., Sedova Z. A. and other Selection of apple trees, M. 1989. -253 p.

[8] Taranova E. A. Apple tree: biology and selection. Riga: Zinatne, 1984. -141 p.

[9] Sadigov A. N. Selection and study of apple varieties in the Guba-Khachmas zone of the Republic of Azerbaijan. Abstract. dis... doctor. S.-kh. sciences. B., 2015. - 42 p.

[10] The program and method for selection of fruit, berry and nutbearing crops of VNIIS; under. obsh. ed. G. A. Lobanova. Michurinsk: VNIISK, 1973. - p. 3-13, 429-473, 487-526.

[11] The program and method of selection of fruit, berry and nut crops / under. ed. E. N. Sedova - Eagle: VNIISPK, 1995.--504 p.

[12] Sedov E. N. Selection of apple trees in the middle lane of the RSFSR. Eagle, 1973-351 pp. 